\title{
PENGARUH DISCHARGE PLANNING BERBASIS VIDEO DENGAN PENDEKATAN FAMILY CENTERED NURSING TERHADAP KEMAMPUAN KELUARGA MERAWAT KLIEN SKIZOFRENIA
}

\author{
Nunik Purwanti ${ }^{1}$ ), Ah. Yusuf ${ }^{2}$ ), Suprajitno ${ }^{3}$ ) \\ 1) Magister Keperawatan Fakultas Keperawatan Universitas Airlangga \\ Email : noniek@unusa.ac.id \\ 2) Fakultas Keperawatan Universitas Airlangga \\ 3) Poltekkes Kemenkes Malang
}

\begin{abstract}
Abstrak: Skizofrenia merupakan gangguan otak kronis yang menyerang sekitar 1 persen dari populasi yang juga sering ditemukan di Indonesia. Data rekam medik dari Rumah Sakit Jiwa Menur Surabaya bulan Juli-September 2016 didapatkan jumlah pasien dengan diagnosis Skizofrenia sebanyak 439 pasien. Kasus skizofrenia meningkat karena dukungan, peran dan kemampuan keluarga dalam merawat klien skizofrenia adalah kurang. Tujuan untuk membuktikan pengaruh Discharge Planning berbasis video dengan pendekatan family centered Nursing terhadap kemampuan keluarga dalam merawat klien skizofrenia. Penelitian ini menggunakan rancangan penelitian quasi eksperimentaldesign (pre-post test control group design). Populasi dalam penelitian ini adalah keluarga klien skizofrenia; sampel penelitian adalah sebagian keluarga klien Skizofrenia. Besar sampel sebanyak 16 responden untuk kelompok kontrol dan 16 responden untuk kelompok perlakuan. Teknik pengambilan sampel menggunakan consecutive random sampling. Variabel independen adalah discharge Planning berbasis video pendekatan family centered Nursing, variabel dependen adalah kemampuan kognitif, kemampuan afektif dan kemampuan psikomotor keluarga. Data dianalis dengan menggunakan Mann-Whitney dan Wilcoxon signed rank test. Analisis uji Mann Whitney didapatkan kemampuan kognitif $\mathrm{P}$ value $0,013<0,05$ berarti ada perbedaan antara kelompok perlakuan dan kelompok kontrol. Variabel kemampuan afektif $\mathrm{P}$ value $0,000<0,05$ berarti ada perbedaan antara kelompok perlakuan dan kelompok kontrol. Variabel kemampuan psikomotor $\mathrm{P}$ value $0,001<0,05$ berarti ada perbedaan kelmpok perlakuan dan kelompok kontrol Pemberian discharge planning memiliki pengaruh pada kemampuan kognitif, afektif, dan psikomotor keluarga dalam merawat klien skizofrenia. Disarankan adanya penyediaan ruangan khusus untuk pelaksanaan discharge planning dan perlu dikembangkan penelitian faktor lain yang mempengaruhi pelaksanaan discharge planning.
\end{abstract}

Kata kunci: Discharge planning, Skizofrenia, Family Center Nursing,

Abstract: Schizophrenia is a chronic brain disorder that affects about one percent of the population which is also commonly found in Indonesia. Based on the medical records taken from Surabaya Menur Mental Hospital in July until September 2016, the number of patients diagnosed with this disease is 439 patients. The increasing case of schizophrenia is resulted from the lack of support and role of family and their ability in taking care of patients with schizophrenia. This study used quasi-experimental design (pre-post test controlgroup design), purposed to prove the effects of video-based discharge planning using family-centered nursing on the ability of family in taking care of patients with schizophrenia. This study involved the family members of schizophrenic clients as the population in which half of them were taken as the samples: 15 repondents were chosen as the control group, whereas 15 respondents were taken as the treatment group using consecutive random sampling technique. The independent 
variable was the video-based discharge planning using family-centered nursing, whereas the dependent variable was the cognitive, affective, and psychomotor ability of the family. Moreover, the data were analyzed by using Mann-Whitney and Wilxocon signed rank test. Mann Whitney test analysis obtained on cognitive ability $\mathrm{P}$ value $0.013<0.05$ means there is a difference between the treatment group and the control group. In affective ability $\mathrm{P}$ value $0,000<0.05$ means there is a difference between the treatment group and the control group. In psychomotor ability $\mathrm{P}$ value $0,002<0,05$ means there are difference of treatment group and control group, so it could be said that the granting of discharge planning affect the family's ability to caring for schizophrenic clients. In conclusion, discharge planning brings effects to the cognitive, affective, and psychomotor ability of the family in taking care of the patients with schizophrenia. Hence, a special room should be available for implementing discharge planning. In addition, this study is expected to be developed by studying other factors that affect the implementation of discharge planning.

Key words: discharge planning, skizofrenia, family centered nursing

\section{PENDAHULUAN}

Skizofrenia merupakan kasus yang paling sering dijumpai. Penyebab yang paling sering terjadi salah satunya adalah kondisi ekonomi yang rendah. Skizofrenia menduduki peringkat ke 4 dari 10 penyakit terbesar di dunia, 1-2 \% rata-rata dari seluruh jumlah penduduk dari suatu wilayah ditemukan mengalami masalah gangguan jiwa. (Stuart dalam Sri Suryaningrum 2013, David 2004, Ferry Efendi \& Makhfudli, 2009). Keperawatan pada Skizofrenia juga bersifat unik, sering kali klien memperlihatkan gejala berbeda untuk kejadian yang sama. (Yusuf et al, 2015).

Berdasarkan penelitian yang dilakukan Noor (2013), di Rumah Sakit Jiwa Menur jumlah pasien skizofrenia kasus lama lebih banyak dibandingkan kasus baru, sedangkan dari data rekam medik tahun 2013 pada triwulan pertama sebanyak 205 pasien baru dan 280 pasien lama. Berdasarkan data dari rekam Medik Rumah Sakit Jiwa Menur Surabaya pada bulan Juli sampai September 2016 didapatkan jumlah pasien kunjungan yang terdiagnosa Skizofrenia yang 439 pasien. Rata-rata jumlah pasien skizofrenia yang ada di ruangan adalah 30 pasien. Menurut Arif (2006) pasien yang mengalami skizofrenia biasanya tidak dapat sembuh total, hampir $80 \%$ pasien mengalami kekambuhan berulang. Angka kekambuhan yang tinggi pada masalah gangguan jiwa memerlukan perawatan yang multidisiplin, melibatkan beberapa ahli diantaranya ahli psikologi, perawat, terapis, dan juga keluarga.

Mengingat banyak stigma yang muncul dimasyarakat, menimbulkan konsekuensi negative tidak hanya bagi penderitanya tetapi juga bagi keluarga diantaranya sikap penolakan, penyangkalan, disisihkan dan diisolasi di masyarakat, menyebabkan keluarga kurang memberikan dukungan pada penderita gangguan jiwa. Berdasarkan penelitian yang dilakukan oleh Suwarsi (2010) tentang hubungan peran serta keluarga dengan frekuensi kekambuhan skizofrenia didapatkan bahwa peran serta keluarga khususnya pada aspek melibatkan klien dalam kunjungan rutin ke Puskesmas, diketahui dalam kriteria cukup (50\%), dan keteraturan keluarga dalam mengontrol pengobatan klien diketahui dalam kriteria cukup (50\%). Kurangnya dukungan dan peran keluarga dalam merawat klien skizofrenia dapat juga disebabkan kurangnya kemampuan mereka mengenai perawatan pada klien skizofrenia. Berdasarkan penelitian yang dilakukan oleh Sri Suryaningrum \& Ice Yulia Wardani (2013) mengenai hubungan antara 
beban keluarga dengan kemampuan keluarga merawat pasien perilaku kekerasan, untuk pengetahuan didapatkan hasil mayoritas responden pengetahuannya sedang $(67,0 \%)$. Untuk sikap didapatkan mayoritas memiliki sikap tidak baik terhadap pasien sebanyak 75 orang.Kemampuan keluarga yang merupakan gabungan dari pengetahuan dan sikap didapatkan hasil responden memiliki kemampuan tidak baik sebanyak 51 orang. Salah satu cara yang dapat digunakan untuk meningkatkan kemampuan keluarga terutama yang ada di rumah sakit adalah dengan mengoptimalkan pemberian pendidikan kesehatan. Pemberian pendidikan kesehatan pada keluarga dengan skizofrenia merupakan salah satu program dalam perawatan kesehatan jiwa, berupa pendekatan bersifat edukatif dan pragmatif. Program pendidikan kesehatan merupakan langkah yang digunakan agar keluarga dapat ikut serta dalam menurunkan faktor resiko yang berhubungan dengan perkembangan gejala perilaku. Pendidikan kesehatan pada keluarga sangat penting dilakukan agar keluarga dapat memberikan support, dan akan mengubah pemahaman keluarga bahwa orang dengan gangguan jiwa dapat hidup dengan baik asalkan pasien dapat mengontrol emosi dan perilakunya. (Ridwan 2013, Ni Made 2010). Pendidikan kesehatan saat di rumah sakit adalah melalui perencanaan pulang (discharge planning).

Discharge planning adalah pengembangan perencanaan ditujukan untuk pasien dan keluarga sebelum mereka meninggalkan rumah sakit. Perencanaan discharge planning yang baik dapat mengurangi pasien tinggal di rumah sakit, sekaligus dapat mengurangi angka kekambuhan. Berdasarkan Tutik (2008) ditemukan masih banyak pelaksanaan discharge planning yang kurang optimal. Berdasarkan upik
(2011) dari hasil studi pendahuluan pada penelitian yang dilakukannya ditemukan bahwa discharge planning dilakukan untuk kelengkapan administrasi catatan resume pulang pasien, diantaranya pemberian informasi yang diberikan berkisar mengenai informasi waktu kontrol, cara minum obat dan perubahan gaya hidup.

Pelaksanaan discharge planning di rumah sakit pada umumnya menggunakan metoda ceramah dan diskusi, penggunaan media atau alat peraga yang digunakan beraneka ragam. Media yang lebih banyak pancaindera yang digunakan memudahkan pengertian, pemahaman dan pengetahuan. Pancaindera yang paling banyak menyalurkan pengetahuan ke mata adalah mata (75\% sampai 87\%).Penggunaan media yang menggunakan pencaindera lebih dari satu diantaranya adalah video. Video merupakan media yang mempunyai ciri menyajikan visual dinamis dan sebelum digunakan dirancang terlebih dahulu, dihasilkan melalui proses mekanik dan elektronik. (Heri DJ, 2009, Kumboyono, 2011).

\section{METODE}

Penelitian ini menggunakan rancangan quasi eksperimental (pre-post test control group design), dengan tujuan untuk membuktikan pengaruh Discharge Planning berbasis video dengan pendekatan family centeredNursing terhadap kemampuan keluarga dalam merawat klien skizofrenia. Pada penelitian ini kelompok eksperimen diberi intervensi discharge planning berbasis videosedangkan kelompok kontrol diberikan discharge planning sesuai dengan standart yang ada di rumah sakit yaitu dengan ceramah.

Populasi dalam penelitian ini keluarga klien skizofrenia yang berada di rumah sakit Jiwa Menur Surabaya.Sampel dalam 
penelitian ini adalah sebagian keluarga klien Skizofrenia Besar sampel dalam penelitian ini sebanyak 16 untuk kelompok kontrol dan 16 untuk kelompok perlakuan. Teknik pengambilan sampel menggunakan consecutif sampling kemudian sampel dibagi menjadi 2 kelompok, yaitu kelompok perlakukan (diberikan discharge planning berbasis video) melalui pendekatan Family Centered Nursing dan kelompok kontrol (hanya diberikan perawatan sesuai prosedur rumah sakit). Variabel independen dalam penelitian ini adalah discharge Planning berbasis video pendekatan family centered Nursing. Variabel dependen dari penelitian ini adalah kemampuan kognitif, kemampuan afektif dan kemampuan psikomotor keluarga dalam merawat klien Skizofrenia.

Analisis menggunakan Uji Mann Whitneydan Wilcoxon merupakan uji nonparametrik yang digunakan untuk membandingkan dua mean populasi yang berasal dari populasi yang sama.

\section{HASIL \& PEMBAHASAN \\ Hasil}

Analisis dengan menggunakan Uji Mann Whitneydan Wilcoxon didaptkan hasil :

Tabel 1. Kemampuan kognitif pada kelompok perlakuan dan kontrol yang diberikan discharge planning dengan pendekatan family centered nursing dalam merawat klien skizofrenia tahun 2017

\begin{tabular}{|c|c|c|c|c|c|c|}
\hline \multirow{2}{*}{$\begin{array}{l}\begin{array}{l}\text { Komponen } \\
\text { variabel }\end{array} \\
\text { Kognitif } \\
\end{array}$} & \multicolumn{6}{|c|}{ Analisis } \\
\hline & \multirow{2}{*}{\multicolumn{2}{|c|}{ mann whitney }} & \multicolumn{4}{|c|}{ Wilcoxon } \\
\hline & & & \multicolumn{2}{|c|}{ perlakuan } & \multicolumn{2}{|c|}{ kontrol } \\
\hline & $\mathrm{Z}$ & $\mathrm{P}$ value & $\mathrm{Z}$ & P Value & $\mathrm{Z}$ & P Value \\
\hline & $-2,47$ & 0,013 & $-3,581$ & 0,000 & $-2,944$ & 0,003 \\
\hline
\end{tabular}

Berdasarkan tabel diatas kemampuan Analisis uji wilxocon signed ranks test responden antara kelompok kontrol dan kemampuan kognitif pada kelompok kelompok perlakuan setelah di analisis perlakuan didapatkan nilai $\mathrm{Z}$ sebesar dengan uji Mann Whitney U didapatkan 3,581 dengan p value (Asymp.sig 2 tailed) bahwa apabila dikonversikan ke nilai $\mathrm{Z}$ sebesar 0,000 0,05 maka ada perbedaan kemampuan kognitif didapatkan $\mathrm{P}$ value antara kelompok pre test dan post test, sebesar $0,0013<0,05$ maka ada perbedaan pada kelompok kontrol $\mathrm{p}$ value $0,003<0,05$ antara kelompok kontrol dengan kelompok berarti ada perbedaan antara pre test dan perlakuan. post

test.

Tabel 2. Kemampuan Afektif pada kelompok perlakuan dan kontrol yang diberikan discharge planning dengan pendekatan family centered nursing dalam merawat klien skizofrenia tahun 2017

\begin{tabular}{|c|c|c|c|c|}
\hline Komponen & \multicolumn{4}{|c|}{ Analisis } \\
\hline \multirow[t]{4}{*}{ Afektif } & mann whitney & \multicolumn{3}{|c|}{ Wilcoxon } \\
\hline & & perlakuan & \multicolumn{2}{|c|}{ kontrol } \\
\hline & $\mathrm{P}$ value & P Value & $\mathrm{Z}$ & P Value \\
\hline & 0,000 & 0,083 & $-0,44$ & 0,655 \\
\hline
\end{tabular}

Kemampuan afektif responden antara setelah di analisis dengan uji Mann kelompok kontrol dan kelompok perlakuan Whitney $U$ didapatkan bahwa apabila 
dikonversikan ke nilai $\mathrm{Z}$ kemampuan afektif didapatkan $\mathrm{P}$ value sebesar $0,000<0,05$ maka ada perbedaan antara kelompok kontrol dengan kelompok perlakuan, berarti ada pengaruh discharge planning pada kelompok perlakuan dan kelompok kontrol. Analisis uji wilxocon signed ranks test kemampuan afektif pada kelompok perlakuan didapatkan nilai $\mathrm{Z}$ sebesar - 1,732 dengan $\mathrm{p}$ value (Asymp.sig 2 tailed) sebesar 0,083>0,05 maka tidak ada perbedaan antara kelompok pre test danpost test, yang berarti tidak ada pengaruh discharge planning pada kelompok pre test dan post test terhadap kemampuan afektif responden. Kelompok kontrol didapatkan nilai $\mathrm{Z}$ sebesar - 0,000 dengan $\mathrm{p}$ value (Asymp.sig 2 tailed) sebesar 1,000> 0,05 maka tidak ada perbedaan antara kelompok pre test dan post test, yang berarti tidak ada pengaruh discharge planning pada kelompok pre test dan post test terhadap kemampuan afektif responden.

Tabel 3. Kemampuan psikomotor pada kelompok perlakuan dan kontrol yang diberikan discharge planning dengan pendekatan family centered nursing dalam merawat klien skizofrenia tahun 2017

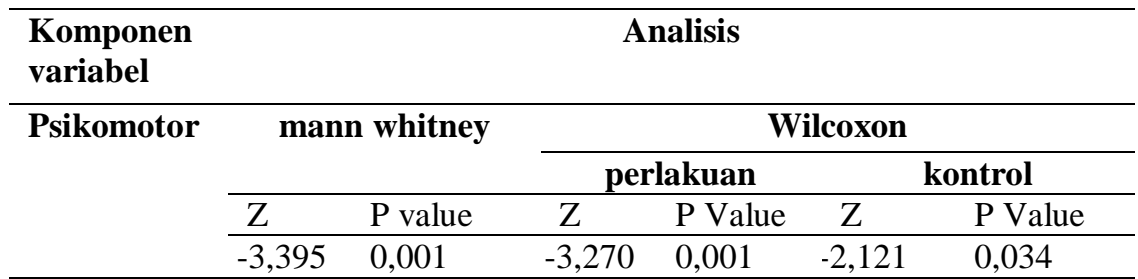

Kemampuan psikomotor responden antara kelompok kontrol dan kelompok perlakuan setelah di analisis dengan uji Mann Whitney U didapatkan bahwa apabila dikonversikan ke nilai $\mathrm{Z}$ kemampuan psikomotor didapatkan $\mathrm{P}$ value sebesar $0,003<0,05$ maka ada perbedaan antara kelompok kontrol dengan kelompok perlakuan, berarti ada pengaruh discharge planning pada kelompok perlakuan dan kelompok kontrol. Analisis uji wilxocon signed ranks test pada kemampuan psikomotor kelompok perlakuan didapatkan nilai $\mathrm{Z}$ perlakuan sebesar 3,071 dengan $\mathrm{p}$ value (Asymp.sig 2 tailed) sebesar 0,002<0,05 maka ada perbedaan antara kelompok pre test dan post test, yang berarti pengaruh discharge planning pada kelompok pre test dan post test terhadap kemampuanpsikomotor responden. Pada kelompok kontrol didapatkan $\mathrm{P}$ value $0,180>0,05$ berarti tidak ada perbedaan antara pre test dan post test.

\section{Pembahasan}

Kemampuan kognitif keluarga pada kelompok perlakuan dan kontrol sebelum dan sesudah diberikan discharge planning berbasis video

Hasil analisis dan interpretasi data yang dilakukan sebelum (pre test) diberikan discharge planning dengan menggunakan media video pada kelompok perlakuan, dan standart rumah sakit pada kelompok kontrol didapatkan bahwa pada kelompok perlakuan dan kelompok kontrol mempunyai kemampuan kognitif pada rentang kurang. Pengetahuan yang di observasi meliputi definisi, tanda dan gejala, faktor penyebab, tujuan dan penatalaksanaan.Berdasarkan rekapitulasi pada hasil kuesioner, didapatkan bahwa responden mengenai definisi secara teori mengenai gangguan jiwa kurang mengetahui, faktor penyebab gangguan jiwa, tujuan dan penatalaksanaan baik pada kelompok perlakuan dan kontrol rata- rata kurang memahaminya. 
Kognitif pada dasarnya merupakan kemampuan intelektual seseorang dalam berpikir, mengetahui dan memecahkan masalah. Menurut teori kognitif dalam Choirul (2017) proses belajar tidak hanya melibatkan stimulus dan respons, tetapi juga melibatkan proses berpikir (kognisi) yang sangat kompleks. Suatu stimulus masuk kedalam otak kita melalui penginderaan, hasil penginderaan akan disimpan dalam otak untuk ditafsirkan dalam proses persepsi. Penyimpanan stimulus agar optimal dalam pemberian informasi memerlukan suatu media yang baik yang dapat dengan mudah diterima oleh pancaindera.Tujuan aspek kognitif berorientasi pada kemampuan berfikir yang mencakup kemampuan intelektual yang lebih sederhana, yaitu mengingat, sampai pada kemampuan memecahkan masalah yang menuntut siswa untuk menghubungkan dan menggabungkan beberapa ide, gagasan, metode atauprosedur yang dipelajari untuk memecahkan masalah tersebut.Dengan demikian aspek kognitif adalah subtaksonomi yang mengungkapkan tentang kegiatan mental yang sering berawal dari tingkat pengetahuan sampai ke tingkat yang paling tinggi yaitu evaluasi.

Penelitian Yusuf, et al (2008) mampu mengubah pikiran negatif menjadi positif dengan terapi kognitif, sedangkan dalam penelitian yang dilakukan peneliti bagaimana discharge planning mengubah individu yang semula tidak tau menjadi tau, individu yang berpikir negatif menjadi berpikir positif. Kognitif sangatlah penting dan menjadi dasar untuk melihatn kemampuan individu yang lainnya. Menurut Potter \& Perry (2005), yang mempengaruhikeberhasilan discharge planningadalah motivasi, sikap, rasa cemas atau emosi, kesehatan fisik, tahap perkembangan dan pengetahuan sebelumnya, kemampuan dalam belajar, serta tingkat pendidikan. Tingkat pendidikan responden dalam penelitian ini adalah berpendidikan tinggi, pendidikan merupakan proses belajar, makin tinggi pendidikan seseorang, makin mudah orang tersebut untuk menerima informasi. Belajar sampai perguruan tinggi orang semakinbanyak pengetahuan yang didapat, ketika seseorang memiliki pengetahuan, maka dia mempunyai senjata dalam karirnya, lebih percaya diri, dan lebih produktif.Belajar sampai jenjang perguruan tinggi dirasakan banyak manfaatnya diantaranya kesempatan kerja yang luas, mempunyai kepribadian dan tanggung jawab, dalam bekerja orang dengan pendidikan tinggi cenderung dalam kemajuan karir jauh lebih mungkin untuk mendapatkan promosi dan membuat kemajuan dalam bidang yang mereka pilih. Berdasarkan analisis dengan uji mann Whitney U didapatkan ada perbedaan antara kelompok perlakuan dan kelompok kontrol. Kognitif pada dasarnya merupakan kajian studi ilmiah mengenai proses mental dan pikiran. Proses ini meliputi bagaimana informasi diperoleh, dipresentasikan dan ditransformasikan sebagai pengetahuan. Pengetahuan itu dimunculkan kembali sebagai petunjuk dalam sikap dan perilaku manusia. Kemampuan individu akan berbeda jika pemberian informasi dan stimulus yang dilakukan juga berbeda. Kelompok perlakuan diberikan informasi mengenai kesehatan klien dengan cara yang berbeda pada kelompok kontrol, otomatis penyerapan informasi dari kedua kelompok juga akan berbeda. Media yang digunakan sangat berperan dalam pencapaian perubahan dari kognitif setiap individu. Pemberian discharge planning yang selama ada menggunakan sistem ceramah, pada penelitian ini menggunakan media yang baru yaitu video. Penyerapan media yang melibatkan dua panca indera menjadi lebih efektif dan mudah untuk di tanggap daya ingat. Pengembangan media 
dalam discharge planning perlu dilakukan terus menerus untuk mendapatkan metode yang sangat efektif dalam membantu individu menjadi lebih mudah menerima informasi yang ada disekitarnya.

\section{Kemampuan afektif keluarga pada kelompok perlakuan dan kontrol sebelum dan sesudah diberikan discharge planning berbasis video}

Hasil analisis dan interpretasi data yang dilakukan sebelum (pre test) diberikan discharge planning dengan menggunakan media video pada kelompok perlakuan, dan standart rumah sakit kemampuan afektif pada kelompok perlakuan baik saat pre test maupun post test mendukung, sedangkan pada kelompok kontrol mempunyai kemampuan afektif pada rentang kurang mendukung. Kemampuan afektif yang dinilai pada penelitian ini adalah difokuskan pada sikap keluarga dalam merawat klien skizofrenia. Sesuai dengan Notoatmojo (2003) pengukuran kemampuan afektif diukur dari attitude (sikap).Sikap dapat dilihat dari kemampuan kognitif, konatif, dan afektif. Kemampuan kognitif dalam sikap menurut Azwar (2016) merupakan kepercayaan seseorang mengenai apa yang berlaku atau apa yang benar bagi objek sikap. Sekali kepercayaan terbentuk, menjadi dasar pengetahuan seseorang mengenai apa yang diharapkan dari objek-objek tertentu. Komponen afektif menyangkut masalah emosional subjektif seseorang terhadap suatu objek sikap, perasaan.Komponen perilaku atau konatif menerangkan bagaimana perilaku atau kecenderungan berperilaku yang ada dalam diri seseorang berkaitan dengan objek sikap yang dihadapi.

Pada kelompok kontrol analisis uji Wilcoxon didapatkan pre test dan post test tidak ada perbedaan, yang berarti tidak ada pengaruh pemberian discharge planning pada sikap responden.Dischargeplanning yang dilakukan pada kelompok kontrol adalah menggunakan standart rumah sakit, dimana pelaksanaan discharge planning disini hanya sebatas pada informasi administrative, obat-obatan, waktu kontrol klien skizofrenia.Pendidikan kesehatan pada keluarga tidak dilakukan diruangan, biasanya di rumah sakit jiwa Menur Surabaya melakukan pendidikan kesehatan masyarakat rumah sakit di poli rawat jalan dan di ruang Wijaya Kusuma. Metode yang dilakukan menggunakan ceramah dandiskusi. Jadi dapat dikatakan bahwa antara pre test dan post test tidak ada perbedaan, karena tidak ada pemberian informasi pada responden.

Pemberian discharge planning pada dasarnya merupakan tugas dan peran perawat di rumah sakit. Peran perawat dalam memberikan discharge planning sangatlah berpengaruh dalam memberikan informasi kepada individu, keluarga, dan klien di rumah sakit, sehingga pemamhaman dan pengetahuan mereka meningkat. Pengetahuan yang meningkat pada diri individu akan memotivasi mereka lebih semangat lagi dalam memberikan perawatan pada klien skizofrenia, sehingga seiring waktu akan mengubah pola fikir mereka dan merubah sikap yang semula negatif menjadi sikap yang positif, yang semula keluarga tidak memberikan dukungan pada klien gangguan jiwa, akhirnya akan memberikan dukungan sepenuhnya pada klien skizofrenia sehingga otomatis angka kejadian skizofrenia dapat dikurangi.

\section{Kemampuan psikomotor keluarga pada kelompok perlakuan dan kontrol sebelum dan sesudah diberikan discharge planning berbasis video}

Hasil analisa dan interpretasi data yang dilakukan sebelum (pre test) diberikan discharge planning dengan menggunakan media video pada kelompok perlakuan, dan 
standart rumah sakit kemampuan psikomotor pada kelompok perlakuan baik saat pre test maupun post test didapatkan ada perbedaan, sedangkan pada kelompok kontrol mempunyai kemampuan psikomotor didapatkan tidak ada perbedaan hasil.

Responden dalam hal kemampuan psikomotor sebagian besar kurang dikarenakan salah satu faktor penyebabnya adalah mereka kurang mendapatkan informasi mengenai bagaimana cara merawat klien skizofrenia. Pendidikan kesehatan yang selama ini ada di Rumah Sakit sudah berjalan, namun secara spesifik bagaimana strategi pelaksanaan pada klien skizofrenia tidak di informasikan.Metode yang digunakan untuk pendidikan masyarakat rumah sakit menggunakan sistem ceramah, sehingga meskipun mereka sudah sering di berikan pendidikan mengenai skizofrenia, responden tidak mampu mengingat secara detail. Pendidikan kesehatan yang berjalan hanya di ruang Wijaya Kususma dan di poli rawat jalan, pada masing-masing ruangan yang ada di Rumah Sakit, pendidikan kesehatan tidak dilakukan, karena keluarga jarang untuk berkunjung, bahkan sulit untuk di kumpulkan.

Pemberian discharge planning yang dilakukan sesuai standart rumah sakit adalah dilakukan sebatas informasi mengenai rawat jalan, kontrol, dan administrasi yang harus diselesaikan oleh responden saat klien sudah dinyatakan pulang. Tidak ada pemberian mengenai informasi mengenai cara merawat klien skizofrenia. Ranah psikomotor merupakan ranah yang berkaitan dengan keterampilan (skill) tau kemampuan bertindak setelah seseorang menerima pengalaman belajar tertentu. Hasil belajar psikomotor ini sebenarnya merupakan kelanjutan dari hasil belajar kognitif (memahami sesuatu) dan dan hasil belajar afektif (yang baru tampakdalam bentuk kecenderungan- kecenderungan berperilaku). Ranah psikomotor adalah berhubungan dengan aktivitas fisik, misalnya lari, melompat, melukis, menari, memukul, dan sebagainya.

Penelitian yang dilakukan oleh Sulistiowati et al, (2010) mengenai pengaruh terapi family psychoeducation terhadap kemampuan keluarga merawat anggota keluarga dengan gangguan jiwa, didapatkan hasil adanya peningkatan kemampuan keluarga secara kognitif dan psikomotor setelah diberikan intervensi baik pada kelompok perlakuan maupun pada kelompok kontrol, hanya saja pada kelompok perlakuan atau intervensi peningkatannya lebih signifikan dibandingkan pada kelompok kontrol. Hal ini pada pelaksanaan terapi FPE pada keluarga dilakukan dengan cara mengajarkan untuk mengidentifikasi masalah-masalah yang terjadi ketika merawat klien serta masalah pribadi keluarga atau care giver sendiri.

Pada kelompok perlakuan ada beberapa responden yang tidak mengalami perubahan dalam kemampuan psikomotor. Pelaksanaan discharge planning menggunakan media video yang dilakukan di ruang rawat inap tidak mempunyai ruangan tersendiri. Pemutaran video discharge planning di lakukan di depan ruang perawatan klien, sehingga untuk konsentrasi ke pemutaran video sangatlah rendah, didukung juga situasi rungan yang sangat ramai. Setelah dilakukan pelatihan secara lansung pada keluarga bagaimana cara merawat klien skizofrenia, lansung dilakukan evaluasi dan selanjutnya responden diberikan $\mathrm{CD}$ mengenai cara perawatan klien skizofrenia untuk di bawa pulang. Pengawasan untuk pemutaran CD di rumah tidaklah dilakukan, hal ini akhirnya yang menjadi sebab responden kelompok perlakuan masih ada yang mempunyai kemampuan psikomotor buruk. Faktor lain yang kemungkinan dapat 
mempengaruhi kemampuan kelompok perlakuan yangmasih buruk setelah pos test adalah kesibukan yang menjadi rutinitas mereka sehari-hari, sehingga CD yang mereka bawa tidak pernah dilihat ataupun diputar untuk memperdalam kemampuan mereka bagaimana cara merawat klien dengan skizofrenia.

\section{KESIMPULAN}

Kesimpulan penelitian merupakansintesa dari pembahasan yang menjawab rumusan masalah dan tujuan penelitian serta hasil dari pembuktian hipotesis. Pemberian discharge planning berbasis video dapat meningkatkan kemampuan kognitif, afektif, dan psikomotor keluarga dalam merawat klien skizofrenia.

\section{DAFTAR PUSTAKA}

Azwar, Saifuddin, 1998, Sikap Manusia, Teori dan Pengukurannya Edisi II, Yogyakarta: Pustaka Pelajar, Yogyakarta.

Aditya Bakti, 2000. Ghazali, Imam, Jhon Castellan, Statistik Non Parametrik, Teori dan Aplikasi dengan Program SPSS,

Ah. Yusuf, Hanik E, \& Zaenal A, 2008, 'Terapi kognitif menurunkan tingkat depresi lansia'.Fakultas keperawatan universitas airlangga kampus c mulyorejo Surabaya.Jurnal ners

Ah. Yusuf, Rizky F, Hanik E. N, 2015, Keperawatan Kesehatan Jiwa, Salemba, Jakarta

Birjandi A, 2008. Discharge Planning Handbook for Healtcare, CRC Press Taylor \& Francis Group, London New York.

Budiman \& Agus, 2013, Kapita Selekta Kuesioner, Pengetahuan dan Sikap dalam Penelitian Kesehatan, Salemba Medika, Jakarta

Cynthia, 2010, Effectiveness of Multimedia instruction in helath professions education compared to traditional instruction

Dayakisni, Tri, Hudaniah, 2003, Psikologi

Sosial ,UMM Press, Malang

Ferry, 2012. Hubungan Tindakan Discharge Planning Perawat Dengan Angka Kekambuhan Pada Pasien Gangguan Jiwa Di Rumah Sakit Jiwa Dr. Radjiman Wediodoningrat Lawang

Faizatur Rohmi, et al, 2015, 'Pengaruh Psikoedukasi Keluarga Terhadap Tingkat Kecemasan dan Kemampuan Keluarga dalam Merawat Penderita TB di Puskesmas Sumbermanjing Wetan kecamatan Sumbermanjing Kabupaten Malang, 'The Indonesian Journal og Helath Science, Vol. 5, No. 2, hal 255- 270

Federer W.T.1963, Experimental design, Theory and application, Oxford and IBH Publishing Co, New Dehi, India

Ferry Efendi \& Makhfudli, 2009, Keperawatan Kesehatan Komunitas Teori dan Praktek dalam Keperawatan, Salemba Medika, Jakarta

Hasan, M. Iqbal, 2002, Pokok-pokok Materi Metodologi Penelitian dan Aplikasinya, PT Ghalia Indonesia, Jakarta.

Hendra S, 2009, Menjadi Manusia Pembelajar, Pt Elex Media Komputindo, Jakarta

Nursalam, 2013,Metodologi Penelitian Ilmu Keperawatan. Edisi 3. Salemba Medika, Jakarta

Nursalam, 2011, Manajemen Keperawatan Aplikasi Dalam Praktek Keperawatan Profesional, Salemba, Jakarta

Nundy, 2013.A Text Messaging Intervention to Improve Heart Failure Self-Management After Hospital Discharge in a Largely African-American Population: Before-After Study 
Made Dian S, Ketut G, Komang A, Ayu S, Ika W, Saputra, 2010, 'Pemberdayaan Keluarga Melalui Pemberian Pendidikan Kesehatan Dalam Merawat Anggota Keluarga dengan Gangguan Jiwa,' Jurnal Keperawatn Jiwa, Vol. 3, No. 2, Hal 141-144

Notoatmojo Soekidjo, (2003). Ilmu Kesehatan Masyarakat, Rineka Cipta, Jakarta,

Riza Firman Suryadi, 2013, Hubungan peran educator perawat dalam discharge planning dengan tingkat kepatuhan pasien rawat inap untuk control di rumah sakit paru kabupaten Jember

Ridwan Kustiawan, 2013, 'Pengaruh pendidikan kesehatan keluarga terhadap kemampuan keluarga merawat klien HDR di kota Tasikmalaya', Cakrawala Galuh, Vol. II, No.7

Rika Damayanti, 'Pengaruh Suportif Keluarga Terhadap Kemampuan Keluarga Merawat klien Gangguan Jiwa di Kecamatan Bogor Timur', 2010
Sunaryo. 2004, Psikologi Untuk Keperawatan, EGC, Jakarta

Suprajitno, 2004, Asuhan Keperawatan Keluarga : Aplikasi Dalam Praktik. EGC, Jakarta

Suryadi, 2013, Hubungan peran educator perawat dalam discharge planning dengan tingkat kepatuhan pasien rawat inap untuk control di rumah sakit paru kabupaten Jember

Saifuddin Azwar, 2016, Sikap Manusia dan Pengukurannya, edisi 2, Pustaka Pelajar, Yogyakarta.

Sri Suryaningrum \& Ice Yulia Wardani, 2013, 'Hubungan antara beban keluarga dengan kemmpuan keluarga merawat pasien perilaku kekerasan di poliklinik rumah sakit Marzoeki Mahdi Bogor, 'Jurnal Keperawatan Jiwa, Vol. 1, No.2, hal. 148-155

Tutik Sri Hariyati, 2010, Developing prototype model of discharge planning with CD Learning media in Indonesia

Upik Rahmi, 2011, 'Pengaruh Discharge Planning Terstruktur Terhadap Kualitas Hidup Pasien Stroke iskemik', Tesis, FIK UI. 